\title{
MEMODELKAN TINGKAT PENGANGGURAN DI KOTA DENPASAR DENGAN PENDUGAAN AREA KECIL EMPIRICAL BAYES
}

\author{
Reynaldo Panji Wicaksono $^{1 \S}$, I Komang Gde Sukarsa ${ }^{2}$, I Putu Eka Nila Kencana ${ }^{3}$ \\ ${ }^{1}$ Program Studi Matematika, Fakultas MIPA - Universitas Udayana [Email : kakareynaldopanji@gmail.com] \\ ${ }^{2}$ Program Studi Matematika, Fakultas MIPA - Universitas Udayana [Email : gedesukarsa@unud.ac.id] \\ ${ }^{3}$ Program Studi Matematika, Fakultas MIPA - Universitas Udayana [Email : i.putu.enk@unud.ac.id] \\ ${ }^{\S}$ Corresponding Author
}

\begin{abstract}
Economic development are described by the unemployment rate. The higher unemployment rate, the weaker economic conditions. Nowadays more policies require information on small areas. The direct estimation does not provide accurate results in smaller areas. Thus the small area estimation becomes an alternative to estimate the parameters. The accuracy depends on the selection of the predictors. In 2019, the unemployment rate in Denpasar is 2,22\%. The result shows that the unemployment rate in each district in Denpasar varies from 0,1\% to 0,3\%
\end{abstract}

Keywords : Small area, empirical Bayes, direct estimation, unemployment

\section{PENDAHULUAN}

Pendugaan area kecil merupakan salah satu teknik statistika yang digunakan dalam menduga parameter yang diinginkan. Saat ini banyak kebijakan yang menghendaki informasi statistik pada area kecil. Kebijakan tersebut di antaranya pada bidang ekonomi, kesehatan, dan pendidikan (Prastesi, 2016). Menurut Rao area kecil dirujuk dari beberapa istilah seperti small area, small domain, minor doman, dan lain sebagainya yang memiliki makna suatu wilayah dengan jumlah sampel yang tidak memadai untuk pendugaan langsung ataupun aspek-aspek kecil yang tidak dapat diestimasi melalui suvei berskala besar ataupun sensus (Rao, 2003).

Pendugaan area kecil memiliki tiga jenis metode yang umum digunakan yaitu empirical best linear unbiased prediction (EBLUP), empirical Bayes (EB), dan hierarchical Bayes (HB) (Fay \& Herriot, 1979). Metode EBLUP dilakukan dengan pendekatan statistika klasik yang menggunakan asumsi varian diketahui namun tidak didasari informasi awal yang dimiliki. Metode EB dan HB dilakukan dengan pendekatan secara statistika Bayes yang menggunakan informasi awal sebaran data (prior) untuk menentukan sebaran hasil (posterior) (Congdon, 2014). Metode EB memiliki langkah perhitungan yang lebih sederhana tanpa menggunakan proses markov chain monte carlo yaitu sebuah proses resampling untuk mengetahui bentuk sebaran dari posterior (Rahman \& Harding, 2017). Hasil Pendugaan area kecil tidak mempertimbangkan banyaknya data sampel seperti pendugaan langsung (Rao, 2003).

Pendugaan area kecil dapat digunakan untuk menduga parameter seperti tingkat pengangguran di suatu wilayah. Penelitian oleh Harsanti (2006) menggunakan metode EBLUP yang menunjukkan bahwa tingkat pengangguran di Kota Bogor dipengaruhi oleh persentase penduduk laki-laki dan persentase bangunan rumah yang tidak permanen (Harsanti, 2006). Kajian oleh Hartono dan Hapsari (2018) menggunakan model zero inflated binomial menunjukkan bahwa tingkat pengangguran dipengaruhi oleh indikator seperti jumlah SMA/SMK/MA dan perguruan tinggi serta surat keterangan miskin yang dikeluarkan oleh pemerintah. (Hartono \& Hapsari, 2018)

Berdasarkan penelitian yang pernah dilakukan sebelumnya, pendugaan area kecil merupakan metode yang dapat digunakan dalam menduga tingkat pengangguran pada area kecil. 
Pendugaan area kecil dapat digunakan untuk menduga tingkat pengangguran di Provinsi Bali yang merupakan salah satu provinsi yang terdampak pandemi Covid-19 tidak hanya pada bidang kesehatan namun juga perekonomiannya. Berdasarkan hukum Okun (Okun's Law) semakin tinggi tingkat pengangguran maka semakin lemah perekonomian di wilayah tersebut (Abel \& Bernanke, 2005). Kota Denpasar yang menjadi pusat perekonomian di Provinsi Bali tentu juga akan terdampak oleh pandemi Covid-19. Merujuk pada data Badan Pusat Statistik Provinsi Bali, pada tahun 2019 tingkat pengangguran di Kota Denpasar mencapai $1,52 \%$ padahal memiliki laju pertumbuhan ekonomi yang tinggi yakni sebesar 5,84\%. Hal ini tentu saja akan meningkat pada tahun 2020 akibat pandemi Covid-19.

Kota Denpasar yang menjadi pusat perekonomian di Provinsi Bali memiliki peran penting dalam setiap kebijakan yang berkaitan dengan sektor ekonomi (Badan Pusat Statistik Kota Denpasar, 2020). Dalam penelitian ini ditentukan besarnya tingkat pengangguran di empat kecamatan di Kota Denpasar melalui pendugaan area kecil. Metode pendugaan area kecil yang digunakan adalah metode empirical Bayes model Poisson-Gamma karena memiliki kelebihan yaitu metode ini menggunakan informasi awal sebaran data sehingga hasil yang diperoleh lebih akurat dengan jumlah sampel yang kecil.

\section{METODE}

Penelitian ini menggunakan data sekunder yang merupakan informasi mengenai variabel penyerta (auxiliary variable) pada tahun 2020 hingga yang diperoleh dari beberapa instansi. Jumlah pengangguran di tiap kecamatan $(Y)$ yang diperoleh dari Badan Pusat Statistik Kota Denpasar, jumlah pasar di tiap kecamatan $\left(X_{1}\right)$ yang diperloeh dari Perumda Pasar Kota Denpasar yang merujuk pada publikasi Badan Pusat Statistik bahwa sebagian besar masyarakat kota Denpasar bekerja pada sektor perdagangan besar dan eceran (Badan Pusat Statistik Kota Denpasar, 2020), jumlah SMA/sederajat di tiap kecamatan $\left(X_{2}\right)$ yang diperoleh dari Dinas Pendidikan, Pemuda, dan Olahraga Kota Denpasar, serta rasio penduduk laki-laki di tiap kecamatan $\left(X_{3}\right)$ yang diperoleh dari Badan Pusat Statistik Kota Denpasar yang keduanya merupakan hasil studi literasi terhadap beberapa penelitian tentang tingkat pengangguran. Variabel penyerta yang digunakan berfokus pada informasi kependudukan karena data sektor perekonomian mengalami penurunan drastis pada tahun 2020 sehingga dapat memberikan hasil yang bias.

Variabel yang dipilih merujuk kepada hasil studi literatur terhadap penelitian sebelumnya yang pernah dilakukan untuk menduga tingkat pengangguran dengan metode yang bervariasi. Penelitian oleh Harsanti (2006) menunjukkan bahwa tingkat pengangguran di Kota Bogor dipengaruhi oleh persentase penduduk laki-laki dan persentase bangunan rumah yang tidak permanen (Harsanti, 2006) serta Kajian oleh Hartono dan Hapsari (2018) menunjukkan bahwa tingkat pengangguran dipengaruhi oleh indikator seperti jumlah SMA/SMK/MA dan perguruan tinggi serta surat keterangan miskin yang dikeluarkan oleh pemerintah (Hartono \& Hapsari, 2018).

Dengan data yang dimiliki dilakukan eksplorasi data terkait variabel penyerta yang digunakan, kemudian dilakukan analisis data dengan menggunakan pendugaan area kecil metode empirical Bayes model PoissonGamma. Teknik pendugaan area kecil dengan metode empirical Bayes model PoissonGamma pada variabel penyerta jumlah pasar di tiap kecamatan $\left(X_{1}\right)$, jumlah SMA/sederajat di tiap kecamatan $\left(X_{2}\right)$, dan rasio penduduk laki-laki di tiap kecamatan $\left(X_{3}\right)$ dimulai dengan mengasumsikan $y_{i} \sim \operatorname{Poisson}\left(e_{i} \mu_{i} \theta_{i}\right) \quad$ independen dengan $\mu_{i}=\mu\left(x_{i}, \beta\right)$ adalah model regresi dengan vektor variabel penyerta $x_{i}=\left(x_{1 i}, x_{2 i}, \ldots, x_{p i}\right)^{T}$ dan vektor koefisien regresi $\quad \beta=\left(\beta_{1}, \beta_{2}, \ldots, \beta_{p}\right)^{T}$. Kemudian diasumsikan $\theta_{i} \sim \operatorname{Gamma}\left(\alpha, \alpha^{-1}\right)$ independen sebagai prior dengan mean 1 dan varian $\frac{1}{\alpha}$ (Rao, 2003). Dengan demikian fungsi likelihood $g\left(y_{i} \mid \theta_{i}\right) \sim \operatorname{Poisson}\left(e_{i} \mu_{i} \theta_{i}\right)$ dan fungsi prior $h\left(\theta_{i}\right) \sim \operatorname{Gamma}\left(\alpha, \alpha^{-1}\right)$ digunakan untuk menentukan fungsi posterior $f\left(\theta_{i} \mid y_{i}\right) \sim \operatorname{Gamma}\left(y_{i}+\alpha, \frac{1}{e_{i} \mu_{i}+\alpha}\right) \quad$ dengan menggabungkan likelihood dan prior melalui statistika Bayes. Sehingga penduga empirical Bayes untuk tingkat pengangguran adalah 
$\hat{\theta}_{i}^{E B}=\frac{e_{i} \widehat{\mu}_{\iota}}{e_{i} \widehat{\mu}_{\iota}+\hat{\alpha}} \widehat{\theta}_{\iota}+\left(1-\frac{e_{i} \widehat{\mu}_{\iota}}{e_{i} \widehat{\mu}_{\iota}+\hat{\alpha}}\right) \widehat{\mu}_{\iota}$

dengan model regresi

$$
\widehat{\mu_{l}}=\exp \left(x_{i}^{T}, \hat{\beta}\right)
$$

Setelah memperoleh model pendugaan area kecil kemudian dilakukan perhitungan terhadap nilai mean square error (MSE) dengan menggunakan metode jackknife. Metode jackknife merupakan sebuah metode yang digunakan untuk mengoreksi bias dari suatu penduga. Pada pendugaan area kecil, metode jackknife digunakan untuk mengoreksi penduga mean square error (MSE) (Kurnia \& Notodiputro, 2006). Penduga MSE jackknife didefinisikan sebagai

$$
\begin{aligned}
& \operatorname{MSE}\left(\hat{\theta}_{i}^{E B}\right)=M_{1 i}+M_{2 i} \\
& M_{1 i} \\
& =g_{1 i}\left(s_{v}^{2}\right) \\
& -\left(\frac{m-1}{m}\right) \sum_{m=1}^{j}\left[\left(g_{1 i}\left(s_{v-1}^{2}\right)\right)\right. \\
& \left.-\left(g_{1 i}\left(s_{v}^{2}\right)\right)\right] \\
& M_{2 i}=\left(\frac{m-1}{m}\right) \sum_{m=1}^{j}\left[\left(\hat{\theta}_{i-1}^{E B}\right)-\left(\hat{\theta}_{i}^{E B}\right)\right]^{2} \\
& g_{1 i}\left(s_{v}^{2}\right)=\left(1-B_{i}\right) s_{v}^{2} \\
& B_{i}=\frac{s_{v}^{2}}{\left(s_{v}^{2}+s_{e i}^{2}\right)}
\end{aligned}
$$

Dari hasil pendugaan area kecil empirical Bayes model Poisson-Gamma yang diperoleh kemudian dihitung nilai mean square error-nya untuk melihat seberapa baik metode pendugaan area kecil empirical Bayes dalam menduga tingkat pengangguran di Kota Denpasar. Dari model pendugaan yang terpilih dilakukan interpretasi model sehingga hasil yang diperoleh dapat dijelaskan dengan fenomena yang ada saat ini semasa pandemi Covid-19

\section{HASIL DAN PEMBAHASAN}

\subsection{Analisis Eksplorasi Data}

Dengan data pada tahun 2020 hingga yang dimiliki dilakukan eksplorasi data terkait variabel penyerta untuk memberikan gambaran mengenai kondisi kependudukan di Kota Denpasr. Variabel penyerta yang berasal dari sektor kependudukan ini kemudian digunakan menduga tingkat pengangguran di Kota Denpasar. Hasil analisis eksplorasi data variabel penyerta pada tahun 2020 ditunjukkan oleh Tabel 3.1

Tabel 3.1 Statistik Deskriptif Variabel Penyerta

\begin{tabular}{ccccc}
\hline Variabel & Mean & Min & Max & $\begin{array}{c}\text { Std. } \\
\text { Dev. }\end{array}$ \\
\hline$X_{1}$ & 3,25 & 2,00 & 7,00 & 2,500 \\
\hline$X_{2}$ & 18,00 & 12,00 & 25,00 & 5,715 \\
\hline$X_{3}$ & 0,5102 & 0,5081 & 0,5112 & 0,001 \\
\hline
\end{tabular}

Tabel 3.1 menunjukkan bahwa setidaknya terdapat dua pasar di tiap kecamatan $\left(X_{1}\right)$ yang berfungsi sebagai lapangan pekerjaan untuk menunjang angkatan kerja yang tersedia. Ratarata jumlah SMA/sederajat di tiap kecamatan $\left(X_{2}\right)$ adalah delapan belas sekolah yang menggambarkan sedikit banyaknya calon angkatan kerja baru. Rata-rata rasio penduduk laki-laki di tiap kecamatan $\left(X_{3}\right)$ adalah 0,5102 yang menunjukkan jumlah laki-laki lebih banyak dibandingkan dengan jumlah perempuan di tiap kecamatan di Kota Denpasar.

\subsection{Pendugaan Tingkat Pengangguran}

Model pendugaan area kecil yang dengan metode empirical Bayes adalah $\widehat{\theta_{l}^{E B}}=$ $\frac{e_{i} \widehat{\mu_{l}}}{e_{i} \widehat{\mu_{l}}+110,1711} \widehat{\theta_{l}}+\left(1-\frac{e_{i} \widehat{\mu_{l}}}{e_{i} \widehat{\mu_{l}}+110,1711}\right) \widehat{\mu_{\imath}}$ dengan $e_{i}$ adalah jumlah pengangguran di tiap kecamatan yang diekspektasikan (diharapkan), nilai $\widehat{\theta}_{l}$ diperoleh melalui pendugaan langsung, dan $\widehat{\mu}_{\imath}$ adalah model regresi Poisson yang didefinisikan $\quad \widehat{\mu}_{l}=\exp \left(-0,68+0,06 X_{1}+\right.$ $\left.0,03 X_{2}-0,07 X_{3}\right)$. Hasil pendugaan tingkat pengangguran di Kota Denpasar pada tahun 2020 dengan pendugaan area kecil model Poisson-Gamma disajikan dalam Tabel 3.2

Tabel 3.2 Pendugaan Area Kecil Tingkat Pengangguran di Kota Denpasar

\begin{tabular}{ccc}
\hline Kecamatan & $\theta^{E B}$ & $M S E\left(\theta^{E B}\right)$ \\
\hline Denpasar Selatan & 0,23 & 0,007 \\
\hline Denpasar Timur & 0,05 & 0,006 \\
\hline Denpasar Barat & 0,17 & 0,007 \\
\hline Denpasar Utara & 0,11 & 0,007 \\
\hline
\end{tabular}

Ketepatan dan keakuratan hasil pendugaan tingkat pengangguran di masing-masing kecamatan di Kota Denpasar digambarkan melalui nilai Mean Square Error (MSE) yang dihitung menggunakan metode Jackknife untuk mengoreksi bias dari estimator. Nilai mean square error yang diperoleh sangat kecil yang menunjukkan bahwa metode pendugaan area 
kecil baik digunakan dalam menduga tingkat pengangguran pada tingkat kecamatan di Kota Denpasar.

\subsection{Interpretasi Model}

Ketepatan dan keakuratan hasil pendugaan digambarkan melalui nilai Mean Square Error (MSE). Semakin kecil nilai MSE yang diperoleh semakin baik hasil pendugaan. Dengan demikian metode pendugaan area kecil baik digunakan dalam menduga tingkat pengangguran pada tingkat kecamatan di Kota Denpasar.

Berdasarkan model pendugaan area kecil yang dipreoleh, terlihat bahwa koefisien $X_{1}$ bernilai positif yang bermakna bahwa peningkatan jumlah pasar di suatu kecamatan meningkatkan nilai dari log ekspektasi tingkat pengangguran hingga 1,06 kali dengan diasumsikan variabel lainnya bernilai konstan. Nilai ini menunjukkan odds kenaikan tingkat pengangguran sesuai dengan meningkatnya jumlah pasar. Pada saat pandemi Covid-19 sebagian besar masyarakat beralif profesi menjadi pedagang yang memberi akibat turunnya permintaan akan barang sehingga para pedagang kembali kehilangan pekerjaan meski jumlah pasar meningkat.

Koefisien $X_{2}$ yang bernilai positif menandakan peningkatan jumlah SMA sederajat di suatu kecamatan meningkatkan nilai dari log ekspektasi tingkat pengangguran hingga 1,03 kali dengan diasumsikan variabel lainnya bernilai konstan. Nilai ini menunjukkan odds kenaikan tingkat pengangguran yang disebabkan oleh banyaknya lulusan yang minim kualifikasi sehingga gagal terserap dalam dunia kerja dan menganggur.

Koefisien $X_{3}$ yang bernilai negatif menandakan peningkatan rasio penduduk lakilaki di suatu kecamatan menurunkan nilai dari log ekspektasi tingkat pengangguran hingga 0,93 kali dengan diasumsikan variabel lainnya bernilai konstan. Nilai ini menunjukkan odds penurunan tingkat pengangguran yang disebabkan oleh banyaknya lapangan pekerjaan yang mengutamakan tenaga dan dalam hal ini laki-laki lebih diutamakan sehingga kenaikan rasio penduduk laki-laki akan menurunkan tingkat pengangguran di Kota Denpasar.

Berdasarkan nilai koefisien variabel penyerta diperoleh model yang bertentangan dengan fenomena pada umumnya. Hal ini terjadi akibat pengaruh variabel penyerta yang ternyata tidak berpengaruh secara langsung terhadap tingkat pengangguran dianalisis dengan meyakini bahwa ada pengaruh secara langsung terhadap tingkat pengangguran. Dengan demikian dapat disimpulkan bahwa dalam penelitian ini variabel-variabel sektor kependudukan tidak berpengaruh langsung terhadap tingkat pengangguran pada tingkat kecamatan di Kota Denpasar.

\section{SIMPULAN DAN SARAN}

Pendugaan area kecil memberikan pendugaan yang baik dalam menduga tingkat pengangguran pada tingkat kecamatan di Kota Denpasar ditunjukkan melalui nilai MSE pendugaan area kecil yang kecil. Model penduga area kecil yang diperoleh melalui metode empirical Bayes model PoissonGamma adalah $\quad \widehat{\theta_{l}^{E B}}=\frac{e_{i} \widehat{\mu_{l}}}{e_{i} \widehat{\mu_{l}}+110,1711} \widehat{\theta_{l}}+$ $\left(1-\frac{e_{i} \widehat{\mu_{l}}}{e_{i} \widehat{\mu_{l}}+110,1711}\right) \widehat{\mu_{l}}$ dengan

$\widehat{\mu_{l}}=\exp \left(-0,68+0,06 X_{1}+0,03 X_{2}-\right.$ $\left.0,07 X_{3}\right)$.

Pada tahun 2020 dugaan tingkat pengangguran Kecamatan Denpasar Selatan adalah $0,23 \%$. Tingkat pengangguran Kecamatan Denpasar Timur adalah 0,05\%. Tingkat pengangguran Kecamatan Denpasar Barat adalah 0,17\%. Tingkat pengangguran Kecamatan Denpasar Utara adalah 0,11\%. Kajian lebih lanjut diperlukan dengan menggunakan metode pendugaan yang lainnya disertai dengan pemilihan variabel penyerta yang lebih beragam untuk memperoleh informasi yang lebih akurat terkait dengan permasalahan tingkat pengangguran di Kota Denpasar.

\section{DAFTAR PUSTAKA}

Abel, A., \& Bernanke, B. 2005.

Macroeconomics. Boston: Pearson/Addison Wesley.

Badan Pusat Statistik Kota Denpasar. 2020. Indikator Kesejahteraan Rakyat Kota Denpasar 2020. Denpasar: Badan Pusat Statistik Kota Denpasar.

Congdon, P. 2014. Applied Bayesian Modelling 2nd ed. New York: John Wiley \& Sons.

Fay, R. E., \& Herriot, R. A. 1979. Estimates of Income for Small Places: An Application of 
James-Stein Procedures to Census Data. J. Am. Stat. Assoc., 74, 269-277.

Kurnia, A., \& Notodiputro, K. A. 2006. Penerapan Metode Jackknife Dalam Pendugaan Area Kecil. Bogor: Department of Statistics, IPB University.

Prastesi, M. 2016. Analysis of Poverty Data by Small Area Estimation. John Wiley \& Sons.

Rahman, A., \& Harding, A. 2017. Small Area Estimation and Microsimulation Modelling. CRC Press.

Rao, J. 2003. Small Area Estimation. John Wiley and Sons. New York. 